\title{
Study of Prevalence of Hepatitis C Virus (HCV) Infection in a Patients attending Tertiary Care Hospital Valsad, Gujarat, India
}

\author{
Parimal H. Patel*, Hiral K. Patel, and Alka B. Nerurkar \\ Department of Microbiology GMERS Medical College, Valsad, Gujarat pin-396001, India \\ *Corresponding author:
}

\author{
A B S T R A C T
}

Keywords

$\mathrm{HCV}$,

Hepatitis C, prevalence, ELISA.

Article Info

Accepted:

26 April 2017

Available Online:

10 May 2017
Hepatitis $\mathrm{C}$ infection is a liver disease caused by the hepatitis $\mathrm{C}$ virus (HCV). It is one of the important risk factor causing acute to chronic illness in form of altered liver functions or development of chronic hepatitis, cirrhosis, hepatocellular carcinoma and liver failure. In India reported prevalence rates vary widely in range of $0.09 \%-2.02 \%$. This retrospective study was carried out in patients attending GMERS hospital, Valsad, South Gujarat during January 2016 to December 2016. Serum samples were collected and screened for antibody against HCV by ELISA method. Result: Of the 7089 patients tested in this period 20 $(0.28 \%)$ were found to be positive for HCV antibody, which includes $10(0.14 \%)$ males and 10(0.14\%) females, the most common affected age group was $\geq 50$ years. Conclusion: The present study highlights current scenario of HCV infection in our tertiary care hospital, it may help to detect target group for early detection and treatment in order to prevent complication.

\section{Introduction}

Hepatitis $\mathrm{C}$ infection is a liver disease caused by the hepatitis $\mathrm{C}$ virus (HCV) (Who hepatitis $\mathrm{C}, 2016)$. It is one of the important risk factor causing acute to chronic illness in form of alter liver function or development of chronic hepattis, cirrhosis, hepatocellular carcinoma and liver failure (Zidan et al., 2012; Farag et al., 2015). $75 \%-85 \%$ of patients develop chronic disease after acute infection which depends upon factor influencing interaction between host and HCV Chen et al., 2006). Prevalence of $\mathrm{HCV}$ infection is variable according to geographical distribution, routes of transmission and other factors. Higher prevalence is found in developing countries where limited resources and facilities are available, Central and east Asia as well as Africa are the most affected region in the world (Preeti et al., 2015; Farag et al., 2015; Who hepatitis C, 2016). According to the World Health Organization (WHO) the prevalence of $\mathrm{HCV}$ infection is up to $3 \%$ of the world's population. In India reported prevalence rates vary widely in range of 0.09\%-2.02\% (Mukhopadhyaya, 2008). In India about 20 million people are known to have Hepatitis $\mathrm{C}$ virus (HCV) infection and a quarter of them expected to develop chronic liver disease in the next 10-15 years (Khaja et al., 2006). The impact of this infection has 
just started to emerge in India. In the absence of efficient anti-HCV screening in our country, the $\mathrm{HCV}$ infection from various sources like will unscreened donors, injection drug use, unsafe injection etc. continue to add to the disease pool (Gowri et al., 2012; Parveen et al., 2015). HCV infection is usually asymptomatic so only few patients are diagnosed during acute phase, those patients who develops chronic HCV infection often undiagnosed because the infection remains asymptomatic, after infection symptoms develop secondary to serious liver damage. There is no vaccine available for hepatitis $\mathrm{C}$ therefore prevention of infection is only depends upon reducing risk of exposure. The aim of this study was to determine the prevalence of Hepatitis $\mathrm{C}$ virus infection in patients attending the tertiary care Hospital at Valsad, South Gujarat, India.

\section{Materials and Methods}

A retrospective study was carried out from January 2016 to December 2016 on patients attending OPD \& IPD at tertiary care hospital. Blood samples of all patients for $\mathrm{HCV}$ testing were collected that referred to the Microbiology laboratory. The serum was separated for the qualitative detection of $\mathrm{HCV}$ antibody by ELISA. The test procedure and interpretation of result was done according to standard protocol and manufacturer's instructions. The test result of patients were noted and analyzed.

\section{Results and Discussion}

The overall prevalence of $\mathrm{HCV}$ infection was $0.28 \%$ (Table 1) and rate of prevalence in both sexes were same.

Prevalence of HCV infection was different in all age group in range 0 to $0.112 \%$. The study showed maximum prevalence of $\mathrm{HCV}$ infection in aged $\geq 50$ years $(0.112 \%)$ (Table
2). Out of total positive maximum number of patients were identified in preoperative screening. Indication wise distribution of patients is shown in table 3 .

Acute HCV infection is usually asymptomatic so infection remains undiagnosed, usually it diagnosed accidentally or when it becomes chronic. It is estimated that only $30-50 \%$ of individuals infected with $\mathrm{HCV}$ are aware of their disease (Rajesh, 2012).

Hepatitis C infection is found worldwide, prevalence rates are also different e.g. 5.5\% in Africa, $4.6 \%$ in the Eastern Mediterranean region, $4 \%$ in the Western Pacific region, 2\% in South East Asia, $1.7 \%$ in the United States of America (USA), 1\% in Europe14 and 28\% in Egypt were noted in past (Sy et al., 2006).

Risk factors for $\mathrm{HCV}$ transmission differ between developed and developing countries. Transmission of HCV was strongly associated with intravenous and percutaneous drug users (IDUs).Studies from the developed countries also reveals that most of the new HCV infection associated with injection drug use (Wasley et al., 2000).

In the developing countries, unsafe therapeutic injections and transfusions are likely to be the major modes of transmission, especially in countries where age-specific seroprevalence rates suggest ongoing increased risk of $\mathrm{HCV}$ infection (Shepard et al., 2005).

The seroprevalence of HCV among general population of India has been reported between 0.22-1.8 per cent (Gowri et al., 2012; Jaiswal et al., 1996).

In our study overall prevalence of $\mathrm{HCV}$ infection is $0.28 \%$ which is similar to study done by Gowri et al., (0.22\%), lower seropositivity was reported from Madurai20, 
while study done by Preeti Mindolii et al., (2.6\%) and Mishra et al., (1.57\%) 21 Showed higher prevalence as compare to our study. Differences in prevalence rates may be due differences in health resources and educational levels awareness of the disease in different regions. The prevalence of $\mathrm{HCV}$ in both genders is controversial. While some studies showed higher HCV incidence among men, other population based surveys showed similar rates in both sexes. In this study prevalence were same for both sexes.

Table.1 Prevalence of Hepatitis C infection among patients in a tertiary care hospital

\begin{tabular}{|c|c|c|}
\hline Total no. of sample received & Total no. of positive sample & $\begin{array}{c}\text { Percentage of total no. of } \\
\text { positive sample }\end{array}$ \\
\hline 7089 & 20 & $0.28 \%$ \\
\hline
\end{tabular}

Table.2 Age-wise prevalence of HCV in hospital based general population

\begin{tabular}{|c|c|c|}
\hline Age group (in years) & $\begin{array}{c}\text { Total no. of positive } \\
\text { patients }\end{array}$ & $\begin{array}{c}\text { Percentage(\%) of total } \\
\text { no. of positive patients }\end{array}$ \\
\hline $0-9$ & 00 & $0 \%$ \\
\hline $10-19$ & 02 & $0.028 \%$ \\
\hline $20-29$ & 05 & $0.070 \%$ \\
\hline $30-39$ & 01 & $0.014 \%$ \\
\hline $40-49$ & 04 & $0.056 \%$ \\
\hline$\geq 50$ & 08 & $0.112 \%$ \\
\hline Total & $\mathbf{2 0}$ & $\mathbf{0 . 2 8} \%$ \\
\hline
\end{tabular}

Table.3 Categorization of Hepatitis c patients according to probable cause

\begin{tabular}{|c|c|c|}
\hline Indication & $\begin{array}{c}\text { No. of HCV positive } \\
\text { patients }\end{array}$ & $\begin{array}{c}\text { Percentage(\%) of HCV } \\
\text { positive patients }\end{array}$ \\
\hline $\begin{array}{c}\text { Symptomatic(Patients admitted in } \\
\text { medical ward) }\end{array}$ & 05 & $25 \%$ \\
\hline Patients attending OPD & 07 & $35 \%$ \\
\hline Pre-operative screening & 08 & $40 \%$ \\
\hline Total & $\mathbf{2 0}$ & $\mathbf{1 0 0} \%$ \\
\hline
\end{tabular}

In patients attending OPD 7 was positive for $\mathrm{HCV}$ and 02 of them were positive for HIV. 
The present study revealed significant trend of $\mathrm{HCV}$ seropositivity with relation to age, highest prevalence was noted in older age group. Study done by Preeti Mindolli et al., also showed similar result, in present study highest prevalence was noted in older age group, may be the reason that late diagnosis in older age group due unavailability of facilities at that time. After older age group significant numbers of $\mathrm{HCV}$ positive patients were found in younger age group (20-29 yr). Intravenous drug abuse is very common in this age group so it can be the first reason of $\mathrm{HCV}$ transmission and early diagnosis due to improvement in health care facilities as well as patients awareness of diseases can be the other reason.

The rate of HIV-HCV confection in the present study was $10 \%$, other studies from India have reported a prevalence of $3.02 \%$ in Andhra Pradesh (Ponamgi et al., 2009), 2.2\% in Tamil Nadu (Saravanan et al., 2007) and $1.6 \%$ in Lucknow (Tripathi et al., 2007) Co infection is due to similarity in mode of transmission.

In conclusion $\mathrm{HCV}$ would be responsible for emerging infection in India. In order to prevent transmission of infection, educational program and screening to target group as well as illiterate people in collaboration with health care provider are require.

\section{References}

Atreyi Chakraborty et al. 2015. A Retrospective Study on the Sero-prevalence of Hepatitis C Infection in a Tertiary Care Hospital in Kolkata, India. Int. J. Curr. Microbiol. App. Sci., 4(3): 115-123.

Chandra, M., Khaja, M.N., Farees, N., Poduri, C.D., Hussain, M.M., Aejaz, H., et al. 2003. Prevalence risk factors and genotype distribution of $\mathrm{HCV}$ and $\mathrm{HBV}$ infection in the tribal population: $A$ community based study in South India. Trop. Gastroenterol., 24: 193-94.

Chandrasekaran, S., Palaniappan, N., Krishnan, V., Mohan, G., Chandrasekaran, N. 2000. Relative prevalence of hepatitis $\mathrm{B}$ viral markers and hepatitis $\mathrm{C}$ virus antibodies (anti HCV) in Madurai, south India. Indian J. Med. Sci., 54: 270-73.

Chen, S.L., Morgan, T.R. 2006. The natural history of hepatitis C virus (HCV) infection. Int. J. Med. Sci., 47-52.

Farag, M.M., Sofy, A.R., Mousa, A.A., Ahmed, M.A., Alganzory, M.R. Molecular Assay and Genotyping of Hepatitis C Virus among Infected Egyptian and Saudi Arabian Patients. Virology (Auckl)., 6:110.

Gao, X., Cui, Q., Shi, X., Su, J., Peng, Z., Chen, X., et al. 2011. Prevalence and trend of hepatitis $\mathrm{C}$ virus infection among blood donors in Chinese mainland: a systematic review and meta-analysis. BMC Infect Dis., 11: 88.

Gowri, V., C. Chandraleka, R. Vanaja. 2012. The Current Seroprevalence of Hepatitis $\mathrm{C}$ Virus in a Tertiary Care Centre in Vellore, Tamil Nadu. Indian $J$. Community Med., Volume: 37 Issue: 2, 37.

Gowri, V., Chandraleka, C., Vanaja, R. 2012. The current seroprevalence of hepatitis $\mathrm{C}$ virus in a tertiary care centre in Vellore, Tamil Nadu. Indian J. Community Med., 37: 137.

Jaiswal, S.P., Chitnis, D.S., Naik, G., Artwani, K.K., Pandit, C.S., Salgia, P., et al., Prevalence of anti-HCV antibodies in central India. Indian J. Med. Res., 104: 177-81.

Khaja, M.N., Madhavi, C., Thippavazzula, R., Nafeesa, F., Habib AM, Habibullah CM, et al. 2006. High prevalence of hepatitis $\mathrm{C}$ virus infection and genotype distribution among general population, blood donors and risk groups. Infect. Genet. Evol., 6: 198-204.

Mishra, S., Chayani, N., Sarangi, G., Mallick, B., Pati, S.B. 2002. Seroprevalence of anti $\mathrm{HCV}$ antibody in and around Cuttack, 
Orissa. Indian J. Med. Microbiol., 20: 401.

Mukhopadhyaya, A. 2008. Hepatitis C in India. J. Biosci., 33: 465-473.

Parisa Ebrahimzadeh, Mohammadreza Haghshena and Farhang Babamahmoodi. The Prevalence of Hepatitis C Virus Genotypes in Mazandaran Province, Iran Jundishapur J. Microbiology.

Parveen Malhotra, Vani Malhotra, Naveen Malhotra, Ishita Singh, Ajay Chugh and Abhishek Chaturvedi. Epidemiological Profile of Hepatitis C Patients at India's New Hub -Haryana Adv. Res. Gastroentero Hepatol., 1(1): ARGH.MS.ID.555554.

Ponamgi, S.P., Rahamathulla, S., Kumar, Y.N., Chandra, M., Lakshmi, N., Habibullah, C.M., et al. 2009. Prevalence of hepatitis $\mathrm{C}$ virus (HCV) coinfection in HIV infected individuals in south India and characterization of $\mathrm{HCV}$ genotypes. Indian J. Med. Microbiol., 27: 12-6.

Preeti, B., Mindolli, Manjunath, P., Salmani. 2015. Seroprevalence of Hepatitis C Virus in a Tertiary Care Centre in Vijaypur, Karnataka, India. Int. J. Curr. Microbiol. Appl. Sci., Volume 4 Number 10: pp. 956-959.

Rajesh, N., Gacche and Sadiq K. Al-Mohani, 2012. "Seroprevalence and Risk Factors for Hepatitis C Virus Infection among General Population in Central Region of Yemen," Hepatitis Research and Treatment, vol. 2012, Article ID 689726, 4 pages, 2012.

Saravanan, S,. Velu, V., Kumarasamy, N., Nandakumar, S., Murugavel, K.G.,
Balakrishnan, P., et al. 2007. Coinfection of hepatiits $\mathrm{B}$ and hepatitis $\mathrm{C}$ virus in HIV infected patients in south India. World $J$. Gastroenterol., 13: 5015-20.

Shepard, C.W., L. Finelli, and M. J. Alter, 2005. "Global epidemiology of hepatitis $\mathrm{C}$ virus infection," The Lancet Infectious Dis., vol. 5, no. 9, pp. 558- 567.

Shobokshi, O.A., F.E. Serebour, A.Z. Al Drees, A.H. Mitwalli, A. Qahtani, and L.I. Skakni. 2003. "Hepatitis C virus seroprevalence rate among Saudis," Saudi Med. J., vol. 24, supplement 2, pp. S81S86.

Sy, T. and M. Mazen Jamal. 2006. "Epidemiology of hepatitis C virus (HCV) infection," Int. J. Med. Sci., vol. 3, no. 2, pp. 41-46, 2006.

Tripathi, A.K., Khanna, M., Gupta, N., Chandra, M. 2007. Low prevalence of hepatitis $\mathrm{B}$ virus and hepatitis $\mathrm{C}$ virus coinfection in patients with human immunodeficiency virus in Northern India. J. Assoc. Physicians India, 55: 429-31.

Wasley, A. and M.J. Alter. 2000. "Epidemiology of hepatitis C: geographic differences and temporal trends," Seminars in Liver Disease, vol. 20, no. 1, pp. $1-16$.

Who hepatitis C fact sheet updated July, 2016.

Zidan, A., Scheuerlein, H., Schule, S., Settmacher, U., Rauchfuss, F. 2012. Epidemiological pattern of hepatitis B and hepatitis $\mathrm{C}$ as etiological agents for hepatocellular carcinoma in iran and worldwide. Hepat Mon., 12(10 HCC).

\section{How to cite this article:}

Parimal H. Patel, Hiral K. Patel, and Alka B. Nerurkar. 2017. Study of prevalence of Hepatitis C virus (HCV) infection in a patients attending tertiary care hospital Valsad, Gujarat, India. Int.J.Curr.Microbiol.App.Sci. 6(5): 2783-2787. doi: https://doi.org/10.20546/ijcmas.2017.605.312 